\title{
Regulations and guidelines on water quality requirements for Managed Aquifer Recharge. International comparison
}

\section{Regolamenti e linee guida sui requisiti di qualità delle acque per la ricarica intenzionale delle falde. Confronto internazionale}

\author{
Enrique Fernández Escalante, Jose David Henao Casas, Ana María Vidal Medeiros, Jon San Sebastián Sauto
}

\begin{abstract}
Riassunto: La ricarica intenzionale delle falde (in inglese Managed Aquifer Recharge, MAR) comprende un insieme di promettenti tecniche per far fronte a una varietà di problemi legati alla gestione dell'acqua. Negli ultimi anni le tecniche MAR hanno visto un'espansione nella loro implementazione e una maggiore accettazione sociale. Tuttavia, vi sono ancora alcune lacune che hanno bisogno di essere affrontate nelle dimensioni scientifiche, economiche e di governance della loro applicazione. Una di queste lacune riguarda la mancanza in molti paesi di norme chiare per l'implementazione della ricarica intenzionale delle falde. In questo studio abbiamo analizzato diciotto norme e dodici linee guida da tutto il mondo sugli standard di qualità delle acque per la ricarica delle falde al fine di favorire l'avanzamento del quadro giuridico. La revisione ha dimostrato che i quadri normativi
\end{abstract}

Keywords: Managed Aquifer Recharge, regulations, guidelines, water quality standards, artificial recharge, Maximum Allowable Concentrations.

Parole chiave: ricarica intenzionale degli acquiferi, norme, linee guida, standard di qualità dell'acqua, ricarica artificiale, massima concentrazione ammissibile.

Enrique FERNÁNDEZ ESCALANTE 㪯"

Departamento de gestión integral del agua, Tragsa, Madrid, Spain efernan6@tragsa.es

\section{Jose David HENAO CASAS}

Departamento de gestión integral del agua, Tragsa, Madrid, Spain Universidad Politécnica de Madrid, Escuela Técnica Superior de Ingeniería Agronómica, Alimentaria y de Biosistemas, Madrid, Spain

\section{Ana María VIDAL MEDEIROS}

Water resources management, World Bank consultant, Montevideo, Uruguay

\section{Jon SAN SEBASTIÁN SAUTO}

Departamento de construcción e ingeniería, Tragsatec, Madrid, Spain

Ricevuto/Received: 19 May 2020 - Accettato/Accepted: 19 June 2020 Pubblicato online/Published online: 30 June 2020

This is an open access article under the CC BY-NC-ND license:

http://creativecommons.org/licenses/by-nc-nd/4.0/

(C) Associazione Acque Sotterranee 2020 esistenti sono implementati a diversi livelli (cioè da regionale a internazionale) e prendono in considerazione diversi aspetti come la pianificazione, l'autorizzazione e il monitoraggio, nonché la valutazione del rischio.

La maggior parte delle normative tiene conto di alcuni di questi aspetti, ma raramente di tutti. Lo studio dettagliato e il confronto degli standard di qualità dell'acqua ha consentito di definire conclusioni relative alle differenze nelle concentrazioni massime ammissibili nelle acque destinate alla ricarica. Inoltre, questo confronto ha reso visibili i diversi approcci per caratterizzare la variabilità dei sistemi MAR e anche le condizioni naturali prevalenti nel corpo idrico sotterraneo ricevente. Sulla base della revisione delle normative selezionate, dei loro vantaggi e carenze, vengono proposte una serie di raccomandazioni per lo sviluppo del futuro quadro giuridico per l'adozione delle tecniche MAR.

Abstract: : Managed Aquifer Recharge (MAR) is a promising set of techniques to cope with a variety of water management-related issues. In recent years MAR implementations have witnessed an expansion and greater social acceptance. Nonetheless, there are still some gaps in the scientific, economic and governance dimensions of MAR which need to be addressed. One of these gaps is the lack in many countries of clear regulations addressing MAR. In this paper eighteen regulations and twelve guidelines on water quality standards from around the world bave been reviewed to favour the advancement of the legal framework concerning $M A R$. The review has demonstrated that the existing MAR regulatory frameworks are implemented at different levels (i.e. from regional to international) and consider different aspects such as planning, permitting and monitoring as well as the risk assessment. Most regulations take into account some of these aspects, but seldom all of them. The detailed study and comparison of the water quality standards enabled to define conclusions regarding the differences in maximum allowable concentrations (MACs). Furthermore, this comparison made visible the different approaches to encompass the variability of $M A R$ systems, and also the natural conditions prevailing in the receiving groundwater body. Based on the review of the selected regulations, their advantages and shortcomings, a series of recommendations are proposed for the development of future legal framework entailing the MAR technique. 


\section{Introduction}

Managed Aquifer Recharge is a set of water management techniques in which water surpluses are injected or infiltrated into aquifers to increase water quantity and quality (Dillon et al. 2009). The increase in groundwater storage can be employed for a variety of purposes, including irrigation (Guyennon et al. 2017), urban water supply (RodríguezEscales et al. 2018), the reversal of aquifer over-exploitation (IAH 2005), the establishment of fresh-water barriers against seawater intrusion (IAH 2005) and as an asset to combat the adverse effect of climate change (Fernández-Escalante et al. 2019). MAR also brings about opportunities; for instance, the Soil Aquifer Treatment in Managed Aquifer Recharge (SATMAR) (Fernández-Escalante et al. 2016) provides treatment of reclaimed water and offers potential for water reuse. The growing acceptance of MAR applications has been reflected into an increasing number of projects around the world, with a MAR implementation rate of about $5 \%$ in volume per year since 1960 (Dillon et al. 2019). It is also worth to mention that MAR may cause adverse effects by displacing and redirecting natural groundwater flow if it is not correctly managed. Consequently, some negative impacts can be expected. For instance, MAR can lead to a high groundwater table in some areas or flooding of crops. However, there is still room for improvement in different areas before the global water sector witnesses a widespread uptake of MAR technologies. One of the most important extents in this regard is the needed improvement of the regulatory framework. To date, only a small number of countries have stepped up with policies concerning environmental and health protection in MAR (Dillon et al. 2009). This situation, which often implies a lack of clear rules and water quality standards, can result in a public misperception of MAR or in implementations which have negative impacts on human health and ecosystems (Valhondo et al. 2020; WHO 2003). Such concern has been recently tangible in Europe, where some experts presented claims and recommendations to the first draft of the regulation on water reuse (JRC 2017). This draft initially considered MAR, but exclusively focused on water reuse for agricultural irrigation, which is critical to avoid risks to health and wellbeing, as a part of the EU's environmental policies EC 2007 and EEA, 2018.

The review and analysis of the existing regulations can help improve the policies regarding MAR. Such improvement entails the identification of weaknesses and strengths and the provision of suggestions. The analysis must be performed in the face of a wide variety of factors, including economic, technical and scientific ones.

Efforts of this kind are taking place around the world. For example, multidisciplinary working groups in Europe produced important proposals in recent years to modify the European Water Framework Directive (WFD), which is the body of law concerning water quality and quantity in the European Union (EU). The European Parliament and the Council of the EU (2013) amended the WFD through the Directive 2013/39, which lays down a strategy to identify priority hazardous substances in water. The Groundwater Directive (2006/118/EC), together with the WFD, presents a solid context under which the development of MAR can be guided (requiring a severe concern for the protection for the augmented body of groundwater). Furthermore, the current work program of the EU WFD Common Implementation Strategy envisages the formulation of a guidance document for ensuring the safe application of MAR as a measure in Member States' River Basin Management Plans (as part of the implementation process of the EU WFD). Guidelines on water reuse in Europe (JRC 2017) led to the first Regulation 2020/741 on minimum requirements for water reuse, published on June 5 2020. Although MAR was initially considered in these guidelines, it is planned to be addressed initially through a Common Implementation Strategy (CIS) Guidance Document.

Yuan et al. (2016) have critically reviewed the MAR regulations concerning this topic (i.e. MAR and water reuse), while Maliva (2020) and Tragsa (2020) have analysed the legal framework entailing MAR in USA and Spain, respectively. To continue with the development of water quality regulations at the European and international levels, and to provide tools to facilitate the analysis of regulations for decisionmakers (including legal frameworks and recommendations from public entities with the ability to influence on future regulations), the present study reviews the existing policies concerning MAR. It focuses on the water quality and regards all regulations independently of the water source, which includes, but not exclusively, reclaimed water in the context of water reuse.

There are more rules and legislation related to MAR apart from the ones included in this study. However, the missing regulations omit water quality standards and their link to MAR systems is not explicit. Most of them are referenced in Bonfanti and Capone (2014) and Capone and Bonfanti (2015).

\section{Methodology}

The sampling of the regulations was carried out in two principal ways: first, a request was extended through the MAR Commission Forum of the International Association of Hydrogeologists (IAH-MAR) in October 2014. The experts in this forum were asked for regulations addressing MAR water quality standards, regardless of the type of MAR system involved and the nature of the jurisdiction in which they apply (i.e. injection/percolation or regional/national). Note that the experts that integrate the debate forum of the IAH-MAR have different backgrounds, such as technical, academic and governmental. Apart from the responses, further regulations were gathered by the authors through a literature review and Internet searches.

The collected documents (including guidelines and public operator's rules too) were grouped in four different categories: 1) Local, which applies to particular projects or cities; 2) Regional, for any specific region inside a country; 3) National, with rules set for an entire nation; and, 4) International, which comprehends regulations intended for several countries. 
The "regulations" have also been classified following the type of MAR system and whether the rules that they provide are "hard" or "soft" in terms of compliance. In this article, "hard" regulations refer to those in which precise instructions of water quality, permitting, management, etc., constrain the operation or implementation of a MAR project. "Soft" guidelines (avoiding the term "regulation" because they do not have binding character) are those that provide not mandatory rules and are mere suggestions. Some of the regulations provide "end of pipe" requirements, i.e., a focus on the qualitative status of the receiving groundwater body. Examples of this sort of rules are the EU WFD in the GWD context, the Italian Decree and the Australian Guidelines.

The reviewed water quality standards were compiled and are provided in a table for easier access, included in an Annex to the present work. These standards are often in the form of Maximum Allowable Concentrations (MACs) and ranges of tolerance.

The MACs dataset was statistically analysed, primarily focusing on frequency and maximum and minimum values; and secondly, based on the analyses of the gathered water quality standards. A proposal for relevant parameters to be considered in MAR operations is also provided.

\section{Results}

A total of 18 guidelines, regulations or public operator rules have been reviewed (Table 1). They pertain to different aspects of the planning, development and operation of MAR systems. Some of the guidelines considered are public operators' rules, but they have the potential to influence on the national level. The main types of MAR techniques involved in the reviewed documents can be further explored in DINA-MAR (2011). These legislations are distributed across the world, as depicted in Figure 1. The categorisation "soft" and "hard" is proposed despite regulations having a legally binding character.

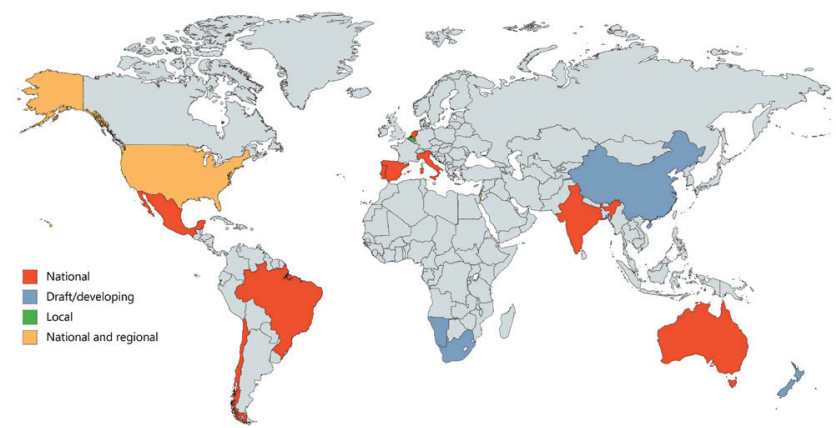

Fig. 1 - Countries which have or are developing legislation on MAR water quality, either at the regional or national level.

Fig. 1 - Paesi che hanno o stanno sviluppando legislazione sulla qualità delle acque per il ravvenamento delle falde, a livello regionale o nazionale.

Tab. 1 -. Summary of the characteristics of the regulations, guidelines and operator rules reviewed (in alphabetical order).

Tab. 1 - Riassunto delle principali caratteristiche delle norme, line guida e norme per gli operatori oggetto della revisione (in ordine alfabetico)

\begin{tabular}{|c|c|c|c|c|c|c|}
\hline Country & Scope & Soft/hard & Type & Year & MACs & $\begin{array}{l}\text { Most used MAR } \\
\text { techniques }\end{array}$ \\
\hline Arizona (USA) & Regional & Hard & Guidelines & 1994 & & ASR*, basins \\
\hline Australia & National & Soft & Guidelines & 2009 & $\mathrm{X}$ & ASR, basins \\
\hline California (USA) & Regional & Hard & Guidelines & 2012 & $\mathrm{X}$ & ASR, SAT-MAR \\
\hline Chile & National & Soft & Regulation & 2013 & & Multiple \\
\hline Florida (USA) & Regional & Soft & Guidelines & 1999 & $\mathrm{X}$ & ASR, basins \\
\hline India & National & Soft & Draft Guidelines & 2014 & & Multiple \\
\hline Italy & National & Hard & Regulation & 2016 & $\mathrm{X}$ & $\mathrm{RBF} * *$ \\
\hline Mexico & National & Hard & Regulation & $2003 \& 2009$ & $\mathrm{X}$ & Basins \\
\hline Portugal & National & Hard & Regulation & 2000 & & Multiple \\
\hline South Africa & National & Hard & Draft regulation & 2004 & & Basins, ASR \\
\hline Spain & National & Hard & Regulation & 2007 & $\mathrm{X}$ & SAT-MAR*** (reuse) \\
\hline The Netherlands & National & Hard & Regulation (under review) & 1993 & $\mathrm{X}$ & SAT-MAR, dunes, ASR \\
\hline Israel (Shafdan) & Local-National $^{1}$ & Hard & Operator rules & From 1966 & $\mathrm{X}$ & SAT-MAR, basins \\
\hline Torreele (Belgium) & Local & Hard & Operator rules & 2012 & $\mathrm{X}$ & SAT-MAR, dunes \\
\hline USA & National & Soft & Regulation & $1974 \& 2019$ & $\mathrm{X}$ & ASR, multiple \\
\hline WFD & International & Soft & Regulation & 2000 & & Basins, ASR \\
\hline WHO guidelines* & - & Soft & Guidelines & 2001 & & SAT-MAR (reuse) \\
\hline Windhoek (Namibia) & National & - & Guidelines. Regulation proposal & 2004 & & Interdune basins, ASR \\
\hline \multicolumn{7}{|c|}{$\begin{array}{l}\text { ASR* Aquifer Storage and Recovery - RBF** River Bank Filtration } \\
\text { SAT-MAR*** Soil \& Aquifer Treatment for Managed Aquifer Recharge }-{ }^{1} \text { Mekorot applies Shafdan's standards to National level } \\
\text { MACs: Maximum Allowable Concentrations - * Legal regulations have a reference framework (international/national etc.). The framework of guidelines is often } \\
\text { based on regional characteristics or settings or is a general outline of common knowledge. }\end{array}$} \\
\hline
\end{tabular}




\section{Local regulations and operator rules}

1. Torreele (Belgium): The Torreele wastewater treatment plant infiltrates effluents through the dunes of the St. André Watershed, constituting a SAT-MAR project. Before infiltration, water is subject to membrane filtration techniques, which account for the stringent water quality standard set in the project. Such standard consist of a collection of nine parameters applied in the whole Flanders Region (Van Houtte 2005), with specific settings. The water source considered is treated wastewater, the MAR technologies addressed by the rules are wells and dunes, and the final use of water is the indirect potable re-use through artificial recharge of the dune aquifer of St-André.

2. Windhoek (Namibia): A draft of water quality standards and regulations are being set by the municipality of Windhoek, the local water supplier in charge of the MAR system and the water affairs department. This draft establishes water quality guidelines with MACs for six parameters, namely Dissolved Organic Carbon (DOC), Assimilable Organic Carbon (AOC), Electrical Conductivity (EC), Chloride, Sulphate and Nitrite/ nitrate. It also set forth a series of principles which must be complied. For instance, MAR should not have a significant negative impact or bring about health risk for the residents in city (GRN 2020). The water sources entailed are multiple (e.g. river water and rainwater); the MAR technologies considered are primarily wells (ASR), and interdune infiltration ponds. The intended end uses of the water are irrigation and environmental purposes.

Operator rules:

3. The Shafdan (Israel): The Shafdan is a SAT-MAR project in which water from the metropolitan area of Tel Aviv (Israel) is reclaimed by way of a wastewater treatment plant and infiltration basins (Goren et al. 2014). This project, which started in 1963, has set 25 MACs, specifying the quality that water must comply prior with infiltration through the soil. Israel's National Water Company, Mekorot, has a certain capacity on regulations drafting and applies these quality standards in all the MAR projects in the country, whilst their proposed list of MACs is finally regulated by the Government. The water source is primarily treated wastewater and to a minor extent desalinated water. The MAR technologies involved are infiltration ponds and ASR, and the final uses of water are irrigation, services for the city and barriers against saline water intrusion.

\section{Regional regulations and guidelines}

1. Arizona (USA): This section of the title 45 (water) belonging to the Arizona statute, sets the definition, mechanism and process to obtain permits of groundwater recharge and Aquifer Storage and Recovery (ASR) (Arizona State Legislature 1994). Additionally, this law defines the ownership of the artificially stored water in the aquifer (Dillon et al. 2019). The water sources considered are treated wastewater, river and rainwater; the guidelines are directed to borehole injection in ASR schemes, infiltration ponds and canals, and the final use of water is varied, with particular regard to the irrigation of golf courses.

2. California (USA): The "Groundwater Replenishment Using Recycled Water" law explicitly addresses the lowthreat ASR projects. It defines the permitting process, the requirements and the water quality standards in water injected and recovered from aquifers (State Water Resources Control Board 2012). Furthermore, the California Department of Public Health (2014) has established a series of rules regarding the replacement of groundwater with recycled water. These include multi-barrier criteria to ensure the safety of the recovered water, hearings before the implementation of a project of this nature and the concept of dilution to remove pollutants reducing the necessity of upgrading wastewater reclamation projects (Yuan et al. 2016). It also requires pilot-testing before full-scale implementation. The water quality standards presented in the Annex correspond to those in the Draft Proposed Groundwater Recharge Regulation (State of California, 1993). The water sources considered are treated wastewater, river and rain water; the MAR technologies addressed are borehole injection (ASR), infiltration ponds and canals, and the final uses of water are multiple.

3. Florida (USA): The regulation Reuse of Reclaimed Water and Land Application sets the requirements to recharge aquifers with reclaimed water via injection wells or infiltration basins (Florida Department of Environmental Protection 1999). For example, for spreading basins, it requests a minimum of secondary treatment and disinfection. For injection wells, the water quality requirements and the pre-treatment are a function of the quality of the native groundwater (Yuan et al., 2016). Furthermore, these water quality standards involve the treatment capacity of the infiltrating medium as well (National Research Council 1998). Apart from controlling reclaimed water reuse, the state of Florida also regulates how to caution areas with water supply problems, and to meet the needs with reclaimed water to a certain extent (National Research Council 1998). The source of water encompassed by this regulation is treated wastewater; the MAR technologies addressed are borehole injection (ASR) and infiltration ponds, and the final uses of water are multiple.

\section{National Regulations and guidelines}

1. Italy: In this country, under the "Decreto 2 maggio 2016, n. 100" (Ministero dell'Ambiente e della Tutela del Territorio e del Mare, 2016) regulation, aquifer recharge is allowed for improving the quality status of the groundwater bodies as per the WFD, and as far as the water employed comes from water bodies which are in good chemical status still according to the WFD/GWD. Recharge is only allowed for groundwater bodies not in good status or for groundwater bodies in good status, but with a standing/negative trend in the presence of pollutants. As 
per the source water, which can only come from surface water or groundwater bodies in good chemical status, this regulation considers the maximum concentration allowed for several substances and parameters (PADs) as defined in the WFD and the Groundwater Directive. Therefore, these quality standards are well adapted to Riverbank Filtration (RBF) and infiltration basins specially allocated near the riverbanks. The Italian regulation also requires one-year monthly hydrodynamic and hydrochemical characteristics monitoring of the aquifer and the donor water body, not only during project design, but during MAR system operation, establishing a quality baseline. Besides, the regulation requires continuous high-frequency monitoring during MAR operations in order to stop operations in case of quality failure. The regulation mentions for its application MAR technologies such as, but not limited to, spreading methods, recharging wells, riverbank filtration, forested infiltration areas, etc. A review on the implementation of MAR in Italy can be found in Rossetto and Bonari (2014) and in Acque Sotterranee, Italian Journal of Groundwater special issue on MAR (Vol.3, n.3, 2014).

2. Spain: The Royal Decree $1620 / 2007$ for water reuse (BOE 2007) is specifically designed for water reuse. It stipulates the water quality standards in MAR considering two situations, either direct percolation (surface recharge using the unsaturated zone as a natural filter) or direct recharge (i.e. injection), either in the unsaturated area at a certain depth (not specified) or directly below the phreatic level. The water quality standards comprehend six parameters, with a particular focus on biological compounds, given the origin of the water (wastewater treatment plants). The water sources are treated wastewater, river and rainwater; the main MAR technologies encompassed are infiltration ponds and canals, and eventually injection boreholes. The intended end use of water is irrigation and in some cases water supply for big cities.

3. The Netherlands: The Infiltratiebesluit Bodembescherming (Infiltration Decree Soil Protection) (Minister van Volkshuisvesting, Ruimtelijke Ordening en Milieubeheer, 1993), updated in 2009, sets forth 65 maximum allowed values for water infiltration through the soil from a surface water body. Additionally, it lists a series of compounds which might be hazardous and gives the provincial executive the competences to rule over these compounds when they are not in negligible concentrations. This regulation additionally considers the end of an infiltration scheme and requires an assessment of the impacts on the soil. If the impacts are negative, remediation is compulsory. This case is a good example of how the high level framework outlined in the WFD and GWD is applied. In particular, these parameters should have been identified as part of the risk assessment undertaken during the development of River Basin Management Plan (risk to achieve good qualitative status). This decree is currently under a new revision. The water source implied is treated wastewater; the MAR technologies addressed are ASR and interdune infiltrations and the final uses of water are irrigation, wetlands restoration and the avoidance of saline water intrusion.

4. Portugal: The Decree-Law 69_2000 of the Ministerio do Ambiente e do Ordenamiento do Territorio (2000) specifies the necessity of an environmental impact assessment for "Groundwater abstraction or artificial recharge of groundwater where the annual volume of water abstracted or recharged is equivalent or greater than 10 million m3/year". The Water Law (Lei 58_2005) (Assembleia da República, 2005) has a reference to MAR in article 30-3: "Prohibition of direct discharges of pollutants in groundwater ... and control of artificial recharge of groundwater, including the establishment of a licensing regime". Therefore, there are no PADs published, but this decree outlines the intention of a proper regulation to address them.

5. USA: The Underground Injection Control Regulations and Safe Drinking Water Act Provisions (USEPA 1974) are a collection of rules which apply to every state in the USA unless a state has its own and more strict regulation (Dillon et al. 2019). One of its objectives is to prevent the endangerment of underground water drinking sources as a consequence of water injection through wells (Maliva, 2020). Therefore, this normative considers MAR systems such as ASR and Aquifer Recharge (AR). It rules the approval and permitting of water injection schemes, as well as their design and operation standards definition. It controls drinking water pollution through maximum contaminant thresholds, which might be determined at the wellhead or some distance away from it, recognising the removal of pollutants through the soil natural attenuation capacity (Maliva 2020). An updated list of the water quality standards for the recharging water (USEPA 2019) is provided in the Annex.

6. Mexico: The "Norma Oficial Mexicana NOM-014CONAGUA-2003" (Official Mexican law norm NOM014-CONAGUA-2003) (CONAGUA, 2009) establishes a water quality standard with maximum allowed values for 95 different compounds and parameters. The "Norma 15" addresses the MAR methodology without any mention to PAD (Conagua 2009). This law concerns treated wastewater and river water as sources and addresses infiltration ponds. The final use of water entailed is, generally, irrigation.

7. Chile (DGA 2013): The "Decreto 203 - Reglamento Sobre Normas de Exploración y Explotación de Aguas Subterráneas" (Decree 203 - Regulation on Norms for the Exploration and Exploitation of Groundwater) (Ministerio de Obras Públicas 2014), in its articles 47 and 48, "regulations on standards", rules the authorisation and the permit systems and defines the required monitoring during MAR operations. Nevertheless, this decree does not provide any water quality standard.

8. Brazil: The National Water Resources Council (CNRH) Resolution 153/2013 regulates MAR at the national level as defined in article 2: "unnatural introduction of water into an aquifer, by planned anthropic intervention, by 
the construction of structures designed for this purpose". This resolution requires MAR projects to have a license from the State Water Management body Authority and studies which certify its technical, economic, health and environmental feasibility (article 5). Another requirement outlined in this resolution is that recharging water must not compromise the aquifer water quality. After the implementation of MAR, the legal officer must maintain a Good Practices Register System (article 9).

9. South Africa: There is a regulation draft from South Africa, unpublished yet. It stipulates the need for licensing to implement MAR systems. Such licensing includes MACs for various parameters and compounds. The permitted MACs consider the aquifer interaction processes and are based on the source water characteristics and the chemistry of the receiving medium (verbal notification). The water sources regarded are multiple; the MAR technologies considered are basins, and ASR and the final uses of water are various, but mainly irrigation.

According to Dillon et al. (2019), China and New Zealand are considering the imminent development of their own MAR regulatory approach, considering the origin of the water, the MAR technologies involved and the final uses. Furthermore, these guidelines will regard health and related environmental issues for each phase.

\section{Guidelines:}

10. Australia: The Australian National Water Quality Management Strategy contains the Australian Guidelines for Water Recycling, which addresses MAR (NRMMC, EPHC, NHMRC 2009). These guidelines are based on risk-management principles which are in accordance with the World Health Organization (WHO) water-safetyplanning approach and are directed to all sources of water, recharge methods and sort of aquifers. Furthermore, these guidelines also contemplate several steps of a MAR project, discussing aspects that go from the office-assessment to the monitoring (Dillon et al. 2019). So far, they have been implemented in three Australian states, namely South Australia, Western Australia and Victoria (Dillon et al. 2020). They do not provide water quality standards in the form of MACs. Instead, these guidelines show a hazard-based and scientific approach, which considers the interactions between the source water and the aquifer. In this sense, they guide the users in the identification and management of hazards, such as pathogens and salinity. They also consider additional pressures involving the MAR system, including the impacts on the ecosystems (Dillon et al. 2020). These guidelines have become a model for future regulations on MAR. The water sources encompassed in these guidelines are treated wastewater, river and rainwater; the MAR technologies considered are borehole injection (ASR), infiltration ponds and canals; and the final use of water is multiple, though mainly oriented on irrigation and environmental purposes.

11. India: The Manual on Artificial Recharge of Ground
Water (CGWB 2007), presents a series of guidelines for the implementation of MAR systems in India, including aspects such as planning, techniques and design of the structures, monitoring of water quantity and quality, economics, operation and maintenance. It discusses several MAR schemes with particular regard to surface spreading, injection wells and gravity wells. Dillon et al. (2014) produced a guideline proposal to prevent aquifer contamination in India through the use of MAR. This guideline includes simple methods to be applied by an untrained person.

\section{International regulations and guidelines}

1. The Water Framework Directive (2000/60/CE, WFD): the EU has adopted a suite of legislation that aims at protecting and managing European water bodies. This task began in 1975 with a Directive 75/440/EEC on surface water quality for drinking water abstraction (Council of the European Communities, 1975). Groundwater had to wait four years more to receive attention, which came with the Directive 80/68/EEC (Council of the European Communities 1979) on the protection of groundwater against pollution caused by a group of dangerous substances.

Subsequently, the WFD (2000/60/CE) set the first effort to regulate both surface water and groundwater, and their interaction. This effort was broadened through the Guidance Document 17 (EC 2007). The text of the 2000/60/ CE contains, at least, five direct references to "artificial recharge" and "reuse" in its articulate. The Article 11(3)(f) introduces a requirement for prior authorisation subjecting MAR to a preventive and limited assessment (in line with Article 4(1)(b)(i)) to ensure that the activity does not hamper its environmental objectives. It demands "controls, including a requirement for prior authorisation of artificial recharge or augmentation of groundwater bodies" and that "these controls shall be periodically reviewed and, where necessary, updated" (Capone and Bonfanti 2015; EC 2012). In short, the WFD impels EU Members to achieve a good qualitative and quantitative status of groundwater bodies. Consequentially, the quality standards of water sources used for MAR are not directly, but indirectly regulated, looking at the effect of MAR on groundwater bodies.

The Groundwater Directive 2006/118/EC (European Parliament and Council of the European Union 2006), in its Article 6(3)(d), develops additional regulations in the form of an exemption to those MAR activities permitted under the WFD. It also considers MAR technologies as a possible measure to achieve the "good status" objectives for water bodies. However, the WFD does not specify implementation strategies, or adopts a limit value approach, but provides strategies to establish good qualitative (ecological and chemical) and quantitative status of all water bodies. The WFD/GWD requires the achievement of good groundwater qualitative status, including the prohibition of local deterioration. Only a few standards available 
(nitrate, ammonium, iron,...) for MAR are regulated (Kübeck and Nottebohm 2016). The catalogue of priority substances in the field of water policy was released in the Directive 2013/39/CE (European Parliament and Council of the European Union 2013), which was a pioneering text regarding pollutants and water quality standards in Europe, applicable also to MAR. It also includes a document for the implementation of the Directive 91/271/EEC (Council of the European Communities 1991) concerning Urban Waste Water Treatment and possibilities for further reuse. The referred parameters form part of a "minimum list" of quality standards and threshold values, and Member States are bound, through the risk assessment undertaken as part of the development of River Basin Management Plan, to agree to the monitoring of this minimum list of parameters whenever a specific risk is identified. It should also be mentioned the Directive on Environmental Impact Assessment 85/337/EEC (2014/52/EU update) which outlines guidelines for MAR schemes larger than $10 \mathrm{Mm}^{3}$.

Guidelines:

2. World Health Organization (WHO): The WHO Guidelines for the Safe Use of Wastewater, Excreta and Greywater, third edition, have been published in four volumes which describe policy-related issues (vol. 1), wastewater reuse in agriculture (vol. 2), and aquaculture (vol. 3) and the use of excreta and greywater in agriculture (vol. 4). These guidelines establish a framework, which allows assessing socio-cultural, environmental, economic and policy aspects of "aquifer recharge", including Public Health risk, risk assessment, regulation, public concerns and communication chapters, and paying special consideration to the reuse of reclaimed water (Yuan et al. 2016). Finally, they encourage countries to adapt the guidelines to "their own social, cultural, economic and environmental conditions" (Ensink and van der Hoek 2009). They are deemed as less strict than those existing in some USA states and in the EU (Yuan et al. 2016). The approach is international, and the guidelines are primarily used in developing countries and as a baseline in jurisdictions without any specific MAR regulation.

\section{Analysis of water quality standards}

From the collection of 18 regulations/guidelines/operator rules gathered, ten present specific water quality standards (for water to be injected or infiltrated), whose compilation is presented in the Annex. The number of parameters regulated by the different standards shows a remarkable difference, from six in Spain's internal regulation (independently of the constraint of the minimum requirements of the Groundwater Directive, being an EU Member State) to 149 in the USA (Fig. 2).

The total number of parameters included in the ten reported water quality standards is 255. Four more are listed in the Australian Guidelines as an ongoing proposal, but they are not normalised yet. These parameters are: Biodegradable Dissolved Organic Carbon (BCOD), Dissolved Organic Carbon (DOC), Membrane Filtration Index (MFI) and UV254 abs.

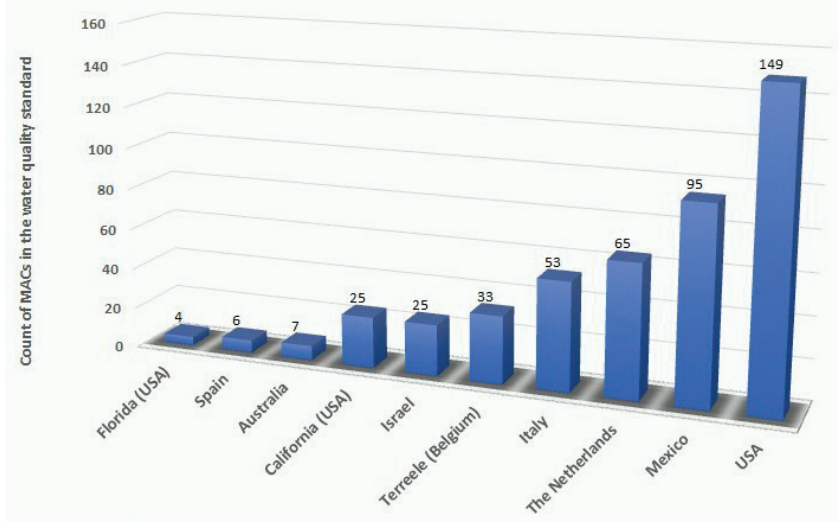

Fig. 2 - Number of parameters per legislation with water quality standards analysed. In the case of the regulations with more than one quality standards, the most stringent one has been considered.

Fig. 2 - Numero di parametri per norma con standard di qualità dell'acqua Nel caso di norme con più di uno standard di qualità, il numero si riferisce allo standard con più parametri.

In water quality standards such as the ones from California, Mexico, and Spain, a distinction is made depending on the type of recharge, either direct injection, percolation, infiltration through ponds or wells, with different limits for each case. For instance, in the Mexican standard, Total Organic Carbon (TOC) must have a value equal or less than $1 \mathrm{mg} / \mathrm{l}$, when water injection is direct, while there is a limit of $16 \mathrm{mg} / \mathrm{l}$ for percolation. In the state of Florida (USA) the legislation goes further and makes four standards based on the sort of recharge and in the receiving medium conditions. Italy categorises the water quality limits for the source water body in two groups, one for the surface water bodies, with standards defined in Table 1 and 2 according to the implementation of the WFD into the Italian regulations (D.Lgs. 152/2006), and the second for the quality of groundwater bodies (including the product of the interaction between groundwater and the water-associated ecosystem; Table 3 in DM 100/2016).

There are two parameters which considerably vary among water quality standards: TOC (x16, which means that the maximum concentration is the minimum multiplied by 16), and Total Suspended Solids (TSS). In Florida, TSS must be below $5 \mathrm{mg} / \mathrm{l}$ while in Mexico, $150 \mathrm{mg} / \mathrm{l}$ (x10) are permitted.

There is a series of parameters which are regulated by most of the standards explored. In general, the Mexican legislation shows the most permissive values, while the strictest ones are found in different standards, but especially in Spain and California. For instance, the total nitrogen has the highest allowed value in Mexico ( $40 \mathrm{mg} / \mathrm{l})$ and the lowest in California and Spain $(10 \mathrm{mg} / \mathrm{l})(\mathrm{x} 4)$. The total phosphorus limit in the Mexican standard is the highest, $20 \mathrm{mg} / \mathrm{l}$, while Belgium has the lowest, namely $0.4 \mathrm{mg} / \mathrm{l}$ (x100). The chloride limit in Mexico is $300 \mathrm{mg} / \mathrm{l}$ and the lowest value is found in the Californian legislation, with $120 \mathrm{mg} / \mathrm{l}$ (x2.5). In the case of sulphates, Mexico shows the highest value again, which is, $300 \mathrm{mg} / \mathrm{l}$, and California the lowest (125 mg/l). An exception is the turbidity, which shows its highest MAC in Israel's standard (10 NTU) and the lowest and most strict in Spain 
Tab. 2 - Proposal of a general list of parameters to be determined in laboratory and field for a MAR-related water sample.

Tab. 2 - Proposta di una lista generale di parametri da determinare in campo e in laboratorio per campioni di acqua da destinare alla ricarica delle falde.

\begin{tabular}{|c|c|}
\hline PARAMETERS (MAR water) & EXPLANATION \\
\hline E.coli & Ecotoxicological aspects. Demanded in most of the regulations (SAT-MAR) \\
\hline Nematodes & Ecotoxicological aspects. Demanded in most of the regulations (SAT-MAR) \\
\hline $\mathrm{pH}$ & Influence on REDOX conditions \\
\hline Temperature & Environmental conditions. Product of solubility, stoichiometry \\
\hline Conductivity & Parameter related to salinization and the total amount of compounds \\
\hline Chemical Oxygen Demand (COD) & Specific parameter for water reuse, to be removed in case of natural water origin (SAT-MAR) \\
\hline $\begin{array}{l}\text { Biochemical Oxygen Demand in } 5 \text { days } \\
\left(\mathrm{BOD}_{5}\right)\end{array}$ & Specific parameter water reuse, to be removed in case of natural water origin (SAT MAR) \\
\hline Total Dissolved oxygen (TDO) & Potential hyper-oxidation conditions and gas clogging creation in the receiving medium \\
\hline Total Organic Carbon (TOC) & Indicator of biological clogging potential and buffer for chemical reactions \\
\hline Total nitrogen $(\mathrm{N})$ & $\begin{array}{l}\text { Residual product after nitrogenised molecules breakdown, e.g. product of diffuse contamination } \\
\text { decomposition }\end{array}$ \\
\hline Total phosphorus $(\mathrm{P})$ & Indicator of biological clogging potential and buffer for chemical reactions \\
\hline Total suspended solids (TSS) & Parameter related to turbidity and demanded in most of the regulations \\
\hline Total Dissolved Solids (TDS) & Parameter related to turbidity and demanded in most of the regulations \\
\hline Turbidity & Parameter requested in most of the regulations \\
\hline Ammonium (NH4) & Residual product after nitrogenised molecules breakdown \\
\hline Nitrates $\left(\mathrm{NO}_{3}{ }^{-}\right)$ & Thick molecules usually trapped in the receiving mediums in which MAR projects take place \\
\hline Sulphates $\left(\mathrm{SO}_{4}\right)$ & Macroconstituents, chemical attack on materials \\
\hline Chloride & Macro, chemical attack on materials, salinity indicator \\
\hline Bicarbonates & Parameter not requested in the regulations but fundamental for hydrochemical calculations \\
\hline Sodium $(\mathrm{Na})$ & Macro, chemical attack on materials, salinity indicator \\
\hline Potassium (K) & Parameter not requested in the regulations but fundamental for hydrochemical calculations \\
\hline Calcium $(\mathrm{Ca})$ & $\begin{array}{l}\text { Parameter not requested in the regulations but fundamental for hydrochemical calculations, } \\
\text { hardness, etc. }\end{array}$ \\
\hline Magnesium $(\mathrm{Mg})$ & $\begin{array}{l}\text { Parameter not requested in some regulations but fundamental for hydrochemical calculations, } \\
\text { hardness, etc. }\end{array}$ \\
\hline Boron (B) & Phytotoxic ion par excellence \\
\hline Silica $(\mathrm{Si})$ & $\begin{array}{l}\text { Determines geochemical environments and biological/chemical reactions. Potential quartz } \\
\text { precipitation }\end{array}$ \\
\hline Arsenic (As) & Ecotoxicological ion par excellence \\
\hline Iron $(\mathrm{Fe})$ & Metal with high effect on physical, chemical and biological clogging generation \\
\hline Manganese $(\mathrm{Mn})$ & Physical, chemical, biological clogging determinant parameter \\
\hline Chromium (Cr) & Physical, chemical, biological clogging determinant parameter. Requested in most of the regulations \\
\hline Copper $(\mathrm{Cu})$ & Special effect on crops. Usual spill from agro-industrial activities \\
\hline Zinc $(\mathrm{Zn})$ & Special effect on crops \\
\hline Fats and oils & Specially for urban areas runoff and SAT-MAR (can be removed for natural river / rain water \\
\hline
\end{tabular}

(2 NTU for the direct injection case) (x5).

Among major ions, nitrate $\left(\mathrm{NO}_{3}^{-}\right)$is the most frequently regulated parameter and is regulated in the standards from The Netherlands, Torreele (Belgium), Spain, Italy, Mexico and the State of Florida (USA). After nitrate, total nitrogen (TN) and total dissolved solids (TSS) are the parameters most frequently regarded in the analysed quality standards.

Regarding (heavy) metal(oid)s, there are substantial differences among the standards. Torreele (Belgium) and the Netherlands are the strictest. For example, the maximum allowable concentration of zinc is $200 \mu \mathrm{g} / \mathrm{l}$ in Torreele and $65 \mu \mathrm{g} / \mathrm{l}$ in The Netherlands (x1/3). On the other hand, California and Mexico propose a lower value of $5 \mathrm{mg} / \mathrm{l}(\mathrm{x} 77)$. The most regulated heavy metals are arsenic, cadmium, lead and mercury, with their MACs reported in seven water quality standards.

An important group of contaminants to consider are the emergent pollutants, which pose a major concern in the reuse of reclaimed water (WHO 2003; Valhondo et al. 2020). The water quality standards from the USA, Italy, México, 
The Netherlands, Shafdan and Torreele take into account these sorts of pollutants. USA, Mexico and The Netherlands stand out for comprehensive regulation of herbicides (e.g. Mecoprop), insecticides (e.g. Mevinphos), and pesticides (e.g. Heptachlor), among other organic compounds. Italy has included in its MAR water quality standard a pioneer methodological approach and recommendations to achieve a "monitored recharge". This approach comprises controls on water quality through continuous high-frequency monitoring, and the proposal of a list of emergent pollutants which must be controlled.

Some major ions such as (bi)carbonates, potassium and calcium (the latter is often determined by means of the water hardness) are missing in most of the standards reported here.

The authors propose a set of generic water quality parameters to be taken into account in MAR projects. These parameters are selected in the face of two factors: 1) the frequency in which they are requested as per the water quality standards reviewed, and 2) their usefulness in hydrogeological tools and hydrochemical calculation (Table 2). This table would constitute a list of essential parameters for MAR. Six of the recommended parameters pertain specifically to SAT-MAR (i.e. MAR with reclaimed water).

On the basis of the results of local risk assessment, additional parameters should be added to ensure safe MAR, taking into consideration the origin of water, MAR technology and use, and, of course, the experts' criteria.

\section{Discussion}

According to the different regulatory approaches reviewed, it can be concluded that the parameters in the water quality standards regarding MAR depend on multiple factors such as the technologies applied (multiple); the environmental conditions (with adaptation mechanisms to every climate, currently under climate change threats); and the final use (e.g. drinking water must complain with higher quality standards than the water used for irrigation or cleaning).

Within this context, there is a complexity in the process to achieve a scientific-based regulation of quality standards, since any adapted multi-barrier and multi-level approach should consider not only hydrogeochemical criteria but all aspects of MAR techniques. Among these MAR features, the most remarkable are the water sources (e.g. treated wastewater, river water, rainwater, etc.); the MAR technologies (taking into consideration the soil and groundwater body, e.g. basin, flooding, well, etc.), and the final use of water (e.g. irrigation of cropland, drinking water, positive hydraulic barriers against seawater intrusion, etc.).

A series of recommendations are provided below to help decision-makers in dealing with the complex task of formulating regulatory and operating framework entailing MAR. These recommendations are based on the review of all the references, and especially on those including problem-solution binomials. The suggestions are divided into those concerning the regulatory framework and those focused on water quality standards, although some of them apply to both categories.

\section{Regulatory framework}

- Developing a common terminology agreement, with legal implications. A homogeneous definition of Artificial Recharge or Managed Aquifer Recharge is thoroughly demanded, at least for the geographical areas which have a common regulation (e.g. the EU). The regulation reviewed hint that there is a shared idea about the MAR concept. Still, the precise meanings are missing in some of them, driving, in case of conflict, to judge's decisions in the absence of widely approved common legal definitions. Such definitions should be compulsory, at least at the European level. In this sense, the WFD should include a legal definition of MAR far from ambiguities (FernándezEscalante and García-Rodríguez 2004). Another practical alternative at the European level would be the development of a Common Understanding between the Member States, such as in a CIS Guidance Document.

- Including a permitting process. Water allocation permits and water extraction rights ownerships must be considered in all regulations and established well in advance, including the simple right of use. At the European level, an authorisation is a requirement of the WFD. What is needed is a riskbased approach to develop the conditions of the permit. This approach could be replicated in other countries.

Some national laws still leave the governments the right to grant permits to regional authorities, as is the case in Spain, while the fundamental right must be the same for all applicants. This aspect of the regulatory framework is especially relevant in the face of pressure on water resources, such as over-exploitation of aquifers or climate change impacts, which can exacerbate water ownership conflicts (Rodríguez-Escales et al. 2018).

- Legal development. There is an insufficient theoretical background on legal aspects of MAR. Furthermore, there are very few countries with a specific regulation on MAR and SAT-MAT. From these, some do not explore in detail the water quality standards, the type of infiltration system or the final use, making difficult for the authorities to grant permits (Sastre-Beceiro 2009).

- Independent control and surveillance. Once an authorisation has been granted, there is a general failure in the mechanisms of control and oversight of the operations. Furthermore, the water-right holder usually provides most of the information and, only in singular cases, the operators, river basin authorities or civil servants taking care of the water quality. A "structured reporting process" should be developed.

- Time continuity. Many experiences have been related to research and development projects. Once such projects come to an end either for budgetary or planning reasons, they are abandoned, and the continuity is, generally, uncertain. The Administration and the Water Basin Authorities should study continuity mechanisms to allow assessing the long-term effects of MAR.

- Inclusion of Budgetary aspects. The financial aspects of MAR projects are frequently excluded in both, the regulations 
and the granting of authorisations. The Water Authorities might request detailed budgets and a certain guarantee of continuity. These demands do not appear in the analysed regulations and guidelines. A certain consideration could be given to positive economic externalities of MAR, e.g. increased water availability, reduction of pumping cost due to a higher water table and blue environmental values. In this way, the unmonetised benefits of MAR would be included in the equation, and a net positive effect of MAR systems would be guaranteed.

- Including the technical background for authorisations. In cases in which local water authorities implement regulations (i.e. implemented at the regional level), there might be slight differences in the monitoring and permission approaches with respect to the national law. Concessions to grant a MAR implementation must take into account the specific water quality standard for an area. It should also require specific studies for the endorsed area duly signed by a competent technician.

Some points of concern are the construction of the MAR facilities, operation and monitoring. The compliance of regulation is in state or operator's control, however, often not fully implemented.-Enhancing technical and legal collaboration. It is essential to study whether the technical solutions proposed to improve the efficiency of any MAR scheme are legal, in accordance with the applicable laws. This aspect could be particularly relevant when dealing with the potential beneficial impact of the unsaturated zone, so important in the final groundwater quality due to interaction processes.

- Moving forward with the WFD. The implementation of MAR and SAT-MAR in the EU may be facilitated by taking the following measures: 1) Establishing a framework of permit or authorisations (EC, 2006); 2) Establishing control and surveillance mechanisms to ensure the implementation of the permit conditions; and 3) Undertaking the necessary oversight of MAR systems to renew any permission or concession (EC, 2007).

\section{Water quality standards}

- Tailoring water quality guidelines based on aquifers and source water. Water standards for MAR must be designed at the aquifer level and taking into account the interactions between the source water and the aquifer. This involves studying the aquifer in-depth and considering the possible sources of water. In this sense, it might be feasible to extend water quality standards across aquifers with similar characteristics. The nation-wide standards seem to be the most straightforward approach, and the aquifer-wide standards would be the safest.

- High number of pollutants to be regulated. MAR possesses great potential in the face of multiple water-related challenges, as long as contamination is minimised. There are scientific uncertainties related to water quality processes and water-mineral interactions. The number of potential pollutants to be analysed may be too large, and their chemical interactions too complex to be demanded by any regulation (Silver, 2016). This situation urges an integrated approach considering water origin (with different degrees of potential pollution), MAR technology and final uses. The WFD allows this flexibility, with threshold values for groundwater being established at the groundwater body level; hence the relevance of the risk-based approach: The more stringent the controls on the quality of the source of water, the fewer parameters would need to be taken into consideration at the end.

- MAR sources and receiving medium considerations. During MAR activities, the receiving medium has a certain capability to remove pollutants, even though the donor water body must be in good chemical status, as appointed in the WFD. A risk analysis approach usually counts on this capability, while water quality standards consider, to a limited extent the aquifer's purification capacity.

Water quality standards should be differentiated according to the MAR technology involved to minimise the impact of the previous points exposed, as it has been done for instance in Spain, Mexico, and the GWD. In these regulations, direct and indirect inputs are taken into consideration following different MAR techniques. It is also important to consider how the impact of the unsaturated zone (not just the aquifer) is taken into account in the legislation.

- Updating some water quality standards. Some pollutants with proved adverse effects on health and the environment are challenging to determine due to high detection limits in laboratories or analytical costs, e.g. NDAs (FernándezEscalante, 2005). In this sense, some specific water quality standards should be reviewed and updated periodically according to the State-Of-The-Art's progress and the instrumental measuring capabilities (for "aquifer-wide" standards).

- Considering the monitoring cost. Guidelines must consider the cost of analysis, especially in developing countries and when the monitoring frequencies are compulsory by law. International institutions such as the IAH-MAR Commission should provide technical support when tailoring MAR regulations and water quality standards.

- Considering monitoring frequencies for each parameter. Water quality guidelines might include additional columns specifying the frequency of monitoring for each parameter and the exact point to collect the samples, e.g. infiltration basin, extraction well, etc.

- Including common parameters. It is advisable to measure major ions such as bicarbonate, calcium and potassium. They are not considered in most of the reviewed regulations, and they are essential in relation to calcite precipitation (chemical clogging) and water processes involved in the hydrogeological methods employed to study groundwater quality and evolution (e.g. hydrograms, ionic relations, and models). The sets of parameters and compounds exposed in Table 2 cover most of the regulated necessities, except for highly polluted environments, in which specific and adapted analyses should be requested. 
- Considering the final use. Water quality standards should also consider the final use of the water for which MAR has been implemented. Domestic water supply is more demanding in terms of water quality than irrigation or industrial uses. Thus, the purification process must be adapted to the final use. Differentiating water quality standards depending on the water needs to be covered (e.g. the 2020/741 Regulation on water reuse (European Parliament 2020)), is controversial. Setting permissive limits for uses which require low water quality (e.g. irrigation) might jeopardise other potential uses (e.g. urban water supply). Even MAR in cities entails certain risks, reduced by means of a proper monitoring, as it is the case of the Shafdan MAR scheme in Israel (Fig. 3).

\section{Conclusions}

Eighteen MAR regulations and guidelines from the local, regional, national and international scope and have been gathered and studied. Furthermore, 10 of these regulations count with water quality standards, which have been compared and analysed.

The regulations reviewed underpin the fact that in many countries, MAR is still considered a new technology. Overall, the policies and legal framework applicable to MAR are scarce and at an early stage, especially in developing countries, where WHO guidelines are widely used.

Some aspects must be addressed in advance when tailoring or amending regulations entailing MAR, such as including a clear permitting system and water ownership rules. Furthermore, common terminology and a legal definition of Managed
Aquifer Recharge/Artificial Recharge should be established.

Regulations should include mechanisms of control and surveillance, ensure sufficient continuity to MAR projects and pilots along the time, and consider budgetary aspects, especially when public investment is involved.

Regarding water quality standards, they should be designed "aquifer-wide" and considering the specific conditions of the aquifer and the source water, as well as the aquifer purifying capacity, the recharging system and the final use. Additionally, concrete monitoring guidelines should be set considering the cost of the analyses, the sampling frequency and the exact point/s to collect each aliquot. Finally, a risk assessment approach should be part of the MAR policies, as exemplified in the Australian Guidelines and the recent European Parliament legislative resolution on minimum requirements for water reuse.

Acknowledgment: This research has been performed within the framework of the MARSOL project (www.marsol.eu) and the MARSoluT Innovative Training Network (MARSoluT-ITN) (https://www.marsolut-itn.eu/). Authors are grateful to all scientists and practitioners who contributed to the request conducted through the IAH MAR Commission Forum. We also thank Manuel Sapiano (Sustainable Energy and Water Conservation Unit, Malta), María Villanueva (Tragsatec; Spain), Rudy Rossetto (Scuola Superiore Sant'Anna, Italy) and Jeff Camkin (University of Western Australia) for their contributions to this article. Finally, we want to express our sincere gratitude to the three anonymous reviewers for their detailed correction and relevant suggestions.

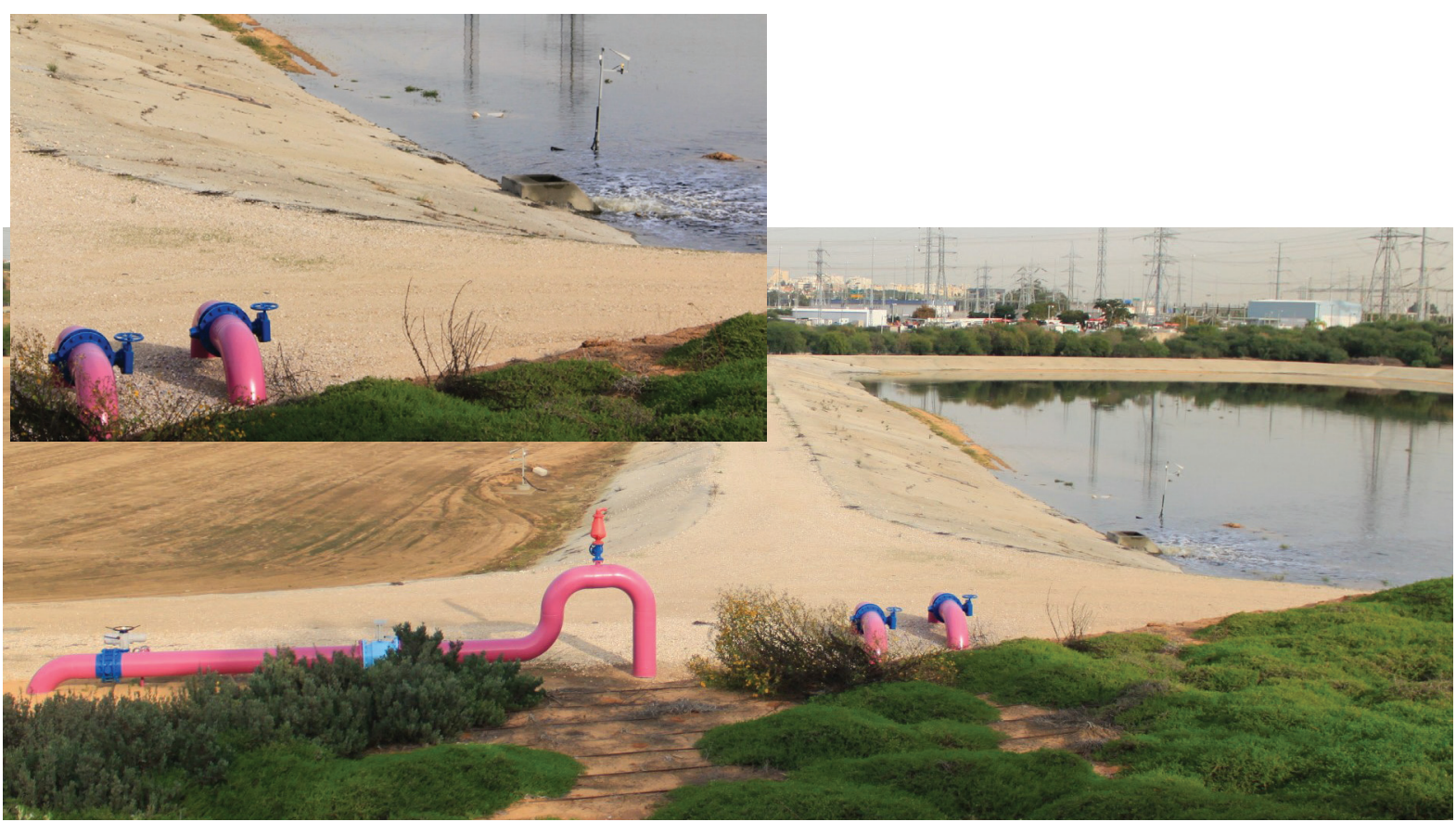

Fig. 3 - MAR regulated system in Shafdan, Israel. Sensors inside the infiltration basins allow the water quality monitoring in real time, in order to attain the standards of quality.

Fig. 3 - Sistema MAR autorizzato a Shafdan, Israele. I sensori all'interno dei bacini di infiltrazione permettono il monitoraggio della qualità dell'acqua in tempo reale, per il controllo degli standard di qualità. 


\section{REFERENCES}

Arizona State Legislature (1994) Underground water storage, savings and replenishment.

Assembleia da República (2005) Lei da Agua Portugal. 2005 Nov. $15^{\text {th }}$. BOE (2007) Real Decreto 1620/2007, de 7 de diciembre, por el que se establece el régimen jurídico de la reutilización de las aguas depuradas "Royal Decree 1620/2007, of December 7th, establishing the legal regime for the reuse of reclaimed water".

California Department of Public Health (2014) DPH-14-003E Groundwater Replenishment Using Recycled Water, Title.

Bonfanti M E, Capone F (2014) A preliminary assessment of the Normative Framework regulating MAR schemes in Europe: the EU Directives and their Implementation in nine National Legislations. Acque Sotterranee - Italian Journal of Groundwater, Vol. 3, n. 3, 2014 https://doi.org/10.7343/as-084-14-0111.

Capone F, Bonfanti ME (2015) Legislative Framework Review and Analysis (Deliverable Nº. D17.1), MARSOL Demonstrating Managed Aquifer Recharge as a Solution to Water Scarcity and Drought. Scuola Superiore Sant'Anna, Pisa, Italy.

CGWB (2007) Manual on Artificial Recharge of Ground Water. Central Ground water Board, New Delhi, India.CNRH, 2009. National Water Resources Council's Resolution 153/2013. Brazil.

CONAGUA (2009) Norma Oficial Mexicana NOM-014-Conagua-2003, Requisitos para la recarga artificial de acuíferos con agua residual tratada, s 17 "Norma Oficial Mexicana NOM-014-Conagua-2003. Requirements for the artificial recharge of aquifers with reclaimed water, s 17 ".

Council of the European Communities (1991) Council Directive of May $21^{\text {st }} 1991$ concerning urban waste water treatment (91/271/EEC). Official Journal of the European Communities 30, 13.

Council of the European Communities (1979) Council Directive of December $17^{\text {th }} 1979$ on the protection of groundwater against pollution caused by certain dangerous substances 80/68/EEC. Official Journal of the European Communities 6.

Council of the European Communities (1975) Council Directive of June $16^{\text {th }} 1975$ concerning the quality required of surface water intended for the abstraction of drinking water in the Member States (75/440/ EEC). Official Journal of the European Communities 6.

DINA-MAR (multiauthor) (2011) Gestión de la recarga artificial de acuíferos en el marco del desarrollo sostenible "). Management of the artificial recharge of aquifers within the framework of sustainable development". ISBN 978-84-614-5123-4, 496 pg.

Dillon P, Page D, Vanderzalm J, Toze S, Simmons C, Hose G, Martin R, Johnston K, Higginson S, Morris R (2020) Lessons from 10 Years of Experience with Australia's Risk-Based Guidelines for Managed Aquifer Recharge. Water 12, 537. https://doi.org/10.3390/ w12020537

Dillon P, Pavelic P, Page D, Beringen H, Ward J. (2009) Managed Aquifer Recharge: An introduction, Waterlines report series no. 13.

Dillon P, Stuyfzand P, Grischek T, Lluria M, Pyne RDG, Jain RC, Bear J, Schwarz J, Wang W, Fernández E, Stefan C, Pettenati M, van der Gun J, Sprenger C, Massmann G, Scanlon BR, Xanke J, Jokela P, Zheng Y, Rossetto R, Shamrukh M, Pavelic P, Murray E, Ross A, Bonilla Valverde JP, Palma Nava A, Ansems N, Posavec K, Ha K, Martin R, Sapiano M (2019) Sixty years of global progress in managed aquifer recharge. Hydrogeol J 27, 1-30. https://doi. org/10.1007/s10040-018-1841-z

Dillon P, Vanderzalm J, Sidhu J, Page D, Chadha D (2014) A Water Quality Guide to Managed Aquifer Recharge in India. CSIRO Land and Water Flagship in Australia and UNESCO International Hydrological Programme.

D. Lgs. 152/2006 Norme in materia ambientale. Gazzetta Ufficiale della Repubblica Italiana n. 88 del 14 aprile 2006 "Legislative Decree 152/2006. Environmental norms. Gazzetta Ufficiale della Repubblica Italiana n. 88 14th april 2006 - Ordinary supplement n $n^{\circ}$ 96" - Supplemento Ordinario n ${ }^{\circ} 96$.
European Commission (2006) Directive 2006/118/EC of the European Parliament and of the Council on the protection of groundwater against pollution and deterioration.

European Commission, EC (2007) Guidance on preventing or limiting direct and indirect inputs in the context of the Groundwater Directive 2006/118/EC. Guidance document $n^{\circ} 17$.

European Commission, EC (2012) Report from the Commission to the European Parliament and the Council on The Implementation of the Water Framework Directive (2000/60/EC) - River Basin Management Plans.

EEA (2018) European waters - assessment of status and pressures 2018 (No. 7). European Environment Agency.

Ensink JHJ, van der Hoek W (2009) Implementation of the WHO guidelines for the safe use of wastewater in Pakistan: balancing risks and benefits. Journal of Water and Health 7, 464-468. https:// doi.org/10.2166/wh.2009.061.

European Parliament and Council of the European Union (2013) Directive 2013/39/EU of the European Parliament and of the Council of August $12^{\text {th }} 2013$ amending Directives 2000/60/EC and 2008/105/ EC as regards priority substances in the field of water policy Text with EEA relevance.

European Parliament and Council of the European Union (2006) Directive 2006/118/EC of the European Parliament and of the Council of December $12^{\text {th }} 2006$ on the protection of groundwater against pollution and deterioration. Official Journal of the European Union 13.

European Parliament and Council of the European Union (2000) Directive 2000/60/EC of the European Parliament and of the Council.

European Parliament (2020) Regulation (EU) 2020/741 of the European Parliament and of the Council of May 25th 2020 on minimum requirements for water reuse. OJEU L 177/32, 5.6.2020.

Fernández-Escalante AE, Calero Gil R, Villanueva Lago M, San Sebastián Sauto J (2016) Managed Aquifer Recharge to combat groundwater overexploitation at the Los Arenales site, Castilla y León, Spain (Deliverable No. D5.4), MARSOL Demonstrating Managed Aquifer Recharge as a Solution to Water Scarcity and Drought. MARSOL, Madrid, Spain.

Fernández-Escalante AE, San Sebastián Sauto J, Calero Gil R (2019) Sites and Indicators of MAR as a Successful Tool to Mitigate Climate Change Effects in Spain. Water 11, 1943. https://doi. org/10.3390/w11091943

Fernández-Escalante E (2005) Recarga artificial de acuíferos en cuencas fluviales. Aspectos cualitativos y medioambientales. Criterios técnicos derivados de la experiencia en la Cubeta de Santiuste, Segovia. Thesis "Artificial recharge of aquifers in river basins. Quality and environmental aspects. Technical criteria obtined from the experience in the Cubeta de Santiuste, Segovia. Thesis". Universidad Complutense de Madrid, Madrid, Spain.

Fernández-Escalante E, García Rodríguez M (2004) La recarga artificial de acuíferos. Marco legal que regula sus aplicaciones. Presentación.

Fernández-Escalante E, San Sebastián Sauto J, Villanueva Lago M and Vidal Medeiros AM (2016) Guidelines for MAR water quality. international overview and lessons learnt. ISMAR 9 Presentación. "Artificial recharge of aquifers. Legal framework regulating its applications. ISMAR 9 Presentation." AIH-GE conference, Zaragoza, 2004. DOI: $10.13140 /$ RG.2.2.14515.43049.

Florida's Department of Environmental Protection (1999) Reuse of reclaimed water and land application, Florida Administrative Code.

Goren O, Burg A, Gavrieli I, Negev I, Guttman J, Kraitzer T, Kloppmann W, Lazar B (2014) Biogeochemical processes in infiltration basins and their impact on the recharging effluent, the soil aquifer treatment (SAT) system of the Shafdan plant, Israel. Applied Geochemistry 48, 58-69.

GRN (2020) Rural Water Supply Programmes and Services. World Bank. 
Guyennon N, Salerno F, Portoghese I, Romano E (2017) Climate change adaptation in a mediterranean semi-arid catchment: testing managed aquifer recharge and increased surface reservoir capacity. Water 9, 689. https://doi.org/10.3390/w9090689.

IAH (2005) Strategies for Managed Aquifer Recharge (MAR) in semiarid areas. United Nations Educational, Scientific and Cultural Organization (UNESCO). Paris, France.

JRC (2017) Development of minimum quality requirements for water reuse in agricultural irrigation and aquifer recharge, Science for Policy. Joint Research Centre, Luxemburg.

Kübeck C, Nottebohm M (2016) Guideline for water quality requirements (deliverable no. 14.4), MARSOL demonstrating managed aquifer recharge as a solution to water scarcity and drought. IWW Water Centre, Leipzig, Germany.

Maliva RG (2020) Anthropogenic Aquifer Recharge: WSP Methods in Water Resources Evaluation Series No. 5, Springer Hydrogeology. Springer International Publishing, Cham. https://doi. org/10.1007/978-3-030-11084-0

Minister van Volkshuisvesting, Ruimtelijke Ordening en Milieubeheer (1993) Infiltratiebesluit bodembescherming "Decree for soil protection infiltration".

Ministerio de Obras Públicas (2014) Decreto 203 - Reglamento Sobre Normas de Exploración y Explotación de Aguas Subterráneas "Decree 203 - Regulation on standards for the exploration and exploitation of groundwater".

Ministério do ambiente e do Ordenamiento do Território (2000) Decreto-Lei n.o 69/2000 de 3 de Maio. Diário da la República - I Série-A 18 "Diary of the Republic".

Ministero dell'Ambiente e della Tutela del Territorio e del Mare (2016) Decreto 2 maggio 2016, n. 100. Gazzetta Ufficiale della Repubblica Italiana, n 13613 giugno 2016, serie generale "Decree 2 may 2016, n. 100. Gazzetta Ufficiale della Repubblica Italiana, n 13613 june 2016, general series".

National Research Council (1998) Issues in potable reuse: the viability of augmenting drinking water supplies with reclaimed water. National Academies Press, Washington, D.C. https://doi. org/10.17226/6022.

NRMMC, EPHC, NHMRC (2009) Australian Guidelines for water recycling, managing health and environmental risks. Natural Resource Management Ministerial Council, Environment Protection and Heritage Council National Health and Medical Research Council.

Rodríguez-Escales P, Canelles A, Sánchez-Vila X, Folch A, Kurtzman D, Rossetto R, Fernández-Escalante E, Lobo-Ferreira JP, Sapiano M, San-Sebastián J et al. (2018) A risk assessment methodology to evaluate the risk failure of managed aquifer recharge in the Mediterranean Basin. Hydrol. Earth Syst. Sci., 22, 3213-3227, doi:10.5194/hess-22-3213-2018.
Rossetto R, Bonari E (2014) The future of Managed Aquifer Recharge in Italy: the European FPVII MARSOL Project and the European Innovation Partnership on Water Mar to Market. Acque Sotterranee - Italian Journal of Groundwater, Vol. 3, n. 3, 2014 https://doi. org/10.7343/as-079-14-0105.

Sastre-Beceiro M (2009) Aspectos jurídicos de la recarga artificial de acuíferos: regulación actual y retos "Legal aspects of artificial recharge of aquifers: current regulation and challenges". Boletín Geológico y Minero 120, 10.

Silver M (2016) Infiltration of treated wastewater through test soils for managed aquifer recharge: water quality changes investigated through soil column experiments. MARSOL final workshop presentation. Leipzig, Germany, October $17^{\text {th }}$ to $19^{\text {th }}$.

State of California (1993) Draft Proposed Groundwater Recharge Regulation. Prepared by the State of California Department of Health Services, Division of Drinking Water and Environmental Management, Sacramento California.

State Water Resources Control Board (2012) General waste discharge requirements for aquifer storage and recovery projects that inject drinking water into groundwater.

Tragsa (2020) Innovación en la Planificación y Gestión del Agua. El Grupo Tragsa y la recarga gestionada de acuíferos "Innovation in water planning and management. Managed aquifer recharge and the Tragsa Group", 48 p. Ed. Tragsa Group, 2020 May.

USEPA (2019) Aquifer recharge and aquifer storage and recovery baseline parameter list. Rule.

USEPA (1974) Underground injection control regulations and safe drinking water act provisions.

Valhondo C, Carrera J, Martínez-Landa L, Wang J, Amalfitano S, Levantesi C, Díaz-Cruz MS (2020) Reactive barriers for renaturalization of reclaimed water during soil aquifer treatment. Water 12, 1012.

Van Houtte E (2005) Artificial recharge of treated wastewater effluent enables sustainable groundwater management of a dune aquifer in Flanders, Belgium, in: Recharge Systems for Protecting and Enhancing Groundwater Resources - Proceedings of the 5th International Symposium on Management of Aquifer Recharge ISMAR 5. Berlin, Germany, pp. 236-246.

WHO (2003) State of the art report health risks in aquifer recharge using reclaimed water. World Health Organization.

WHO (2006) WHO Guidelines for the safe use of wastewater, excreta and greywater, 3rd Ed. World Health Organization.

Yuan J, Van Dyke MI, Huck PM (2016) Water reuse through managed aquifer recharge (MAR): assessment of regulations/guidelines and case studies. Water Quality Research Journal 51, 357-376. https:// doi.org/10.2166/wqric.2016.02 


\section{ANNEX}

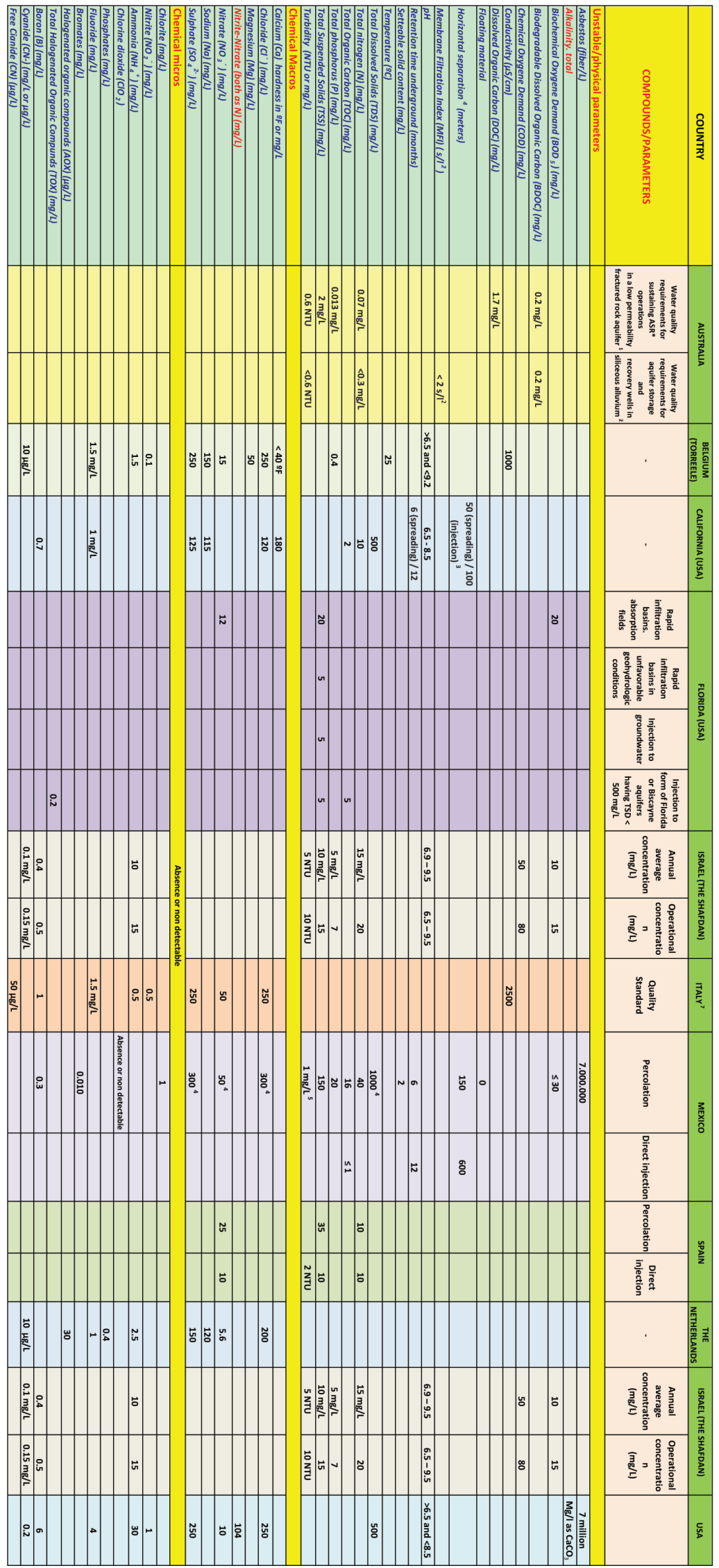




\begin{tabular}{|c|c|c|c|c|c|c|c|c|c|}
\hline COUNTRY & AUSTRALIA & & FLORID & (USA) & & MEXICO & & SP & \\
\hline COMPOUNDS/PARAMETERS & \begin{tabular}{|c|} 
Water quality \\
requirements for \\
sustaining ASR* \\
operations \\
in a low perreability \\
fractured rock aquifier ${ }^{1}$
\end{tabular} & $\begin{array}{c}\text { Rapid infiltration } \\
\text { basins. } \\
\text { absorption fields }\end{array}$ & $\begin{array}{c}\text { Rapid infiltration } \\
\text { basins in } \\
\text { unfavorable } \\
\text { geohydrologic } \\
\text { conditions }\end{array}$ & $\begin{array}{l}\text { Injection to } \\
\text { groundwater }\end{array}$ & \begin{tabular}{|c|} 
Injection to form \\
of Florida \\
or Biscayne \\
aquifers \\
having TSD \\
$500 \mathrm{mg} / \mathrm{L}$
\end{tabular} & Percolation & $\begin{array}{c}\text { Direct } \\
\text { injection }\end{array}$ & Percolation & $\begin{array}{c}\text { Direct } \\
\text { injection }\end{array}$ \\
\hline Bacteria & & & & & & & & & \\
\hline Faecal Coliforms (f.c $/ 100 \mathrm{ml}$ ) & & 200 & Non detectable & Non detectable & Non detectable & Non detectable & & & \\
\hline E.coli (UFC/100 mL) & & & & & & Removal or inactivation & \begin{tabular}{|c|} 
Total Removal or \\
inactivation
\end{tabular} & 1.000 & 0 \\
\hline Nematodes (egg/10 L) & & & & & & & & & 1 \\
\hline Cryptosporidium (mg/L) & & & & & & Absence or non detectable & & & \\
\hline Vibrio cholerae ( $\mathrm{mg} / \mathrm{L}$ ) & & & & & & Absence or non detectable & & & \\
\hline Giardia lamblia (mg/L) & & & & & & Absence or non detectable & & & \\
\hline Bacteria count (mg/L) & & & & & & Absence or non detectable & & & \\
\hline$H P C(\mathrm{mg} / \mathrm{L})$ & & & & & & Absence or non detectable & & & \\
\hline Legionella $(\mathrm{mg} / \mathrm{L})$ & & & & & & Absence or non detectable & & & \\
\hline Enterovirus (mg/L) & & & & & & Absence or non detectable & & & \\
\hline$U V_{254} a b s(\mathrm{~cm}-1)$ & 0.02 & & & & & & & & \\
\hline COUNTRY & BELGIUM (TORREELE) & $\begin{array}{c}\text { CALLFORNIA } \\
\text { (USA) }\end{array}$ & ISRAEL (THE & SHAFDAN) & & ITALY ${ }^{7}$ & MEXICO & \begin{tabular}{|c|} 
THE \\
NETHERLANDS \\
\end{tabular} & USA \\
\hline COMPOUNDS/PARAMETERS & - & - & $\begin{array}{c}\text { Annual average } \\
\text { concentration } \\
(\mathrm{mg} / \mathrm{L})\end{array}$ & $\begin{array}{l}\text { Operational } \\
\text { concentration } \\
(\mathrm{mg} / \mathrm{L})\end{array}$ & $\begin{array}{l}\text { Quality } \\
\text { Standard }\end{array}$ & $\begin{array}{l}\text { Surface water } \\
\text { interaction }\end{array}$ & Percolation & - & \\
\hline (Heavy) metal(loids)s & & & & & & & & & \\
\hline Aluminium (Al) (mg/l) & 0.2 & 1 & & & & & & & 0.2 \\
\hline Antimony $(S b)(\mu g / L)$ & 10 & & & & 5 & & 0.006 & & 0.006 \\
\hline Arsenic (As) $(m g / L \text { or } \mu g / L)^{6}$ & & $0.05 \mathrm{mg} / \mathrm{L}$ & $0.1 \mathrm{mg} / \mathrm{L}$ & $0.15 \mathrm{mg} / \mathrm{L}$ & $10 \mu \mathrm{g} / \mathrm{L}$ & $0.08 / 0.09 \mu \mathrm{g} / \mathrm{L}$ & $0.05 \mathrm{mg} / \mathrm{L}^{5}$ & $10 \mu \mathrm{g} / \mathrm{L}$ & 0.01 \\
\hline Barium $(B a)(\mathrm{mg} / \mathrm{L}$ or $\mu \mathrm{g} / \mathrm{L})$ & & $1 \mathrm{mg} / \mathrm{L}$ & $1 \mathrm{mg} / \mathrm{L}$ & $2 \mathrm{mg} / \mathrm{L}$ & & & $1 \mathrm{mg} / \mathrm{L}^{5}$ & $200 \mu \mathrm{g} / \mathrm{L}$ & 2 \\
\hline Beryllium (Be) $(\mathrm{mg} / \mathrm{L})$ & & & & & & & 0.004 & & 0.004 \\
\hline Cadmium (Cd) $(\mathrm{mg} / \mathrm{L}$ or $\mu \mathrm{g} / \mathrm{L}$ ) & & $0.01 \mathrm{mg} / \mathrm{L}$ & $0.01 \mathrm{mg} / \mathrm{L}$ & $0.025 \mathrm{mg} / \mathrm{L}$ & $5 \mu \mathrm{g} / \mathrm{L}$ & $0.15 / 0.25 \mu \mathrm{g} / \mathrm{L}$ & $0.01 \mathrm{mg} / \mathrm{L}^{5}$ & $0.4 \mu \mathrm{g} / \mathrm{L}$ & 0.005 \\
\hline Chromium total (Cr) $(m g / L$ or $\mu g / L)$ & $50 \mu \mathrm{g} / \mathrm{L}$ & $0.05 \mathrm{mg} / \mathrm{L}$ & $0.08 \mathrm{mg} / \mathrm{L}$ & $0.12 \mathrm{mg} / \mathrm{L}$ & $50 \mu \mathrm{g} / \mathrm{L}$ & & $0.05 \mathrm{mg} / \mathrm{L}^{5}$ & $2 \mu \mathrm{g} / \mathrm{L}$ & \\
\hline Chromium VI (Cr VI) $(\mu \mathrm{g} / \mathrm{L})$ & & & & & $5 \mu \mathrm{g} / \mathrm{L}$ & & & & 0.1 \\
\hline Cobalt $(\mathrm{Co})(\mathrm{mg} / \mathrm{L}$ or $\mu \mathrm{g} / \mathrm{L})$ & & $0.2 \mathrm{mg} / \mathrm{L}$ & $0.05 \mathrm{mg} / \mathrm{L}$ & $0.1 \mathrm{mg} / \mathrm{L}$ & & & & $20 \mu \mathrm{g} / \mathrm{L}$ & \\
\hline Copper (Cu) $(\mathrm{mg} / \mathrm{L}$ or $\mu \mathrm{g} / \mathrm{L})$ & $100 \mu \mathrm{g} / \mathrm{L}$ & & $0.2 \mathrm{mg} / \mathrm{L}$ & $0.5 \mathrm{mg} / \mathrm{L}$ & & & $1 \mathrm{mg} / \mathrm{L}^{5}$ & $15 \mu \mathrm{g} / \mathrm{L}$ & 1.3 \\
\hline Iron $(\mathrm{Fe})(\mathrm{mg} / \mathrm{L})$ & $0.2 \mathrm{mg} / \mathrm{L}$ & $0.3 \mathrm{mg} / \mathrm{L}$ & $1.5 \mathrm{mg} / \mathrm{L}$ & $2.5 \mathrm{mg} / \mathrm{L}$ & & & $0.3 \mathrm{mg} / \mathrm{L}$ & & 5 \\
\hline Lead $(P b)(m g / L$ or $\mu g / L)$ & $20 \mu \mathrm{g} / \mathrm{L}$ & $0.05 \mathrm{mg} / \mathrm{L}$ & $0.1 \mathrm{mg} / \mathrm{L}$ & $0.2 \mathrm{mg} / \mathrm{L}$ & $10 \mu \mathrm{g} / \mathrm{L}$ & $7.2 \mu \mathrm{g} / \mathrm{L}$ & $0.05 \mathrm{mg} / \mathrm{h}^{5}$ & $15 \mu \mathrm{g} / \mathrm{L}$ & 0.015 \\
\hline Manganese (Mn) (mg/L) & $0.05 \mathrm{mg} / \mathrm{L}$ & $0.05 \mathrm{mg} / \mathrm{L}$ & $0.2 \mathrm{mg} / \mathrm{L}$ & $0.5 \mathrm{mg} / \mathrm{L}$ & & & $0.05 \mathrm{mg} / \mathrm{L}^{5}$ & & 0.3 \\
\hline Mercury $(\mathrm{Hg})(\mathrm{mg} / \mathrm{L} \mathrm{or} \mu \mathrm{g} / \mathrm{L})$ & $1 \mu \mathrm{\mu g} / \mathrm{L}$ & $0.002 \mathrm{mg} / \mathrm{L}$ & $0.002 \mathrm{mg} / \mathrm{L}$ & $0.005 \mathrm{mg} / \mathrm{L}$ & $1 \mu \mathrm{g} / \mathrm{L}$ & $0.03 \mu \mathrm{g} / \mathrm{L}$ & $0.002 \mathrm{mg} / \mathrm{L}^{5}$ & $0.05 \mu \mathrm{g} / \mathrm{L}$ & 0.002 \\
\hline Molybdenum $(\mathrm{Mo})(\mathrm{mg} / \mathrm{L})$ & & & $0.01 \mathrm{mg} / \mathrm{L}$ & $0.02 \mathrm{mg} / \mathrm{L}$ & & & & & 0.04 \\
\hline Nickel (Ni) (mg/L or $\mu g / L)$ & $50 \mu \mathrm{g} / \mathrm{L}$ & & $0.2 \mathrm{mg} / \mathrm{L}$ & $0.5 \mathrm{mg} / \mathrm{L}$ & $20 \mu \mathrm{g} / \mathrm{L}$ & & & $15 \mu \mathrm{g} / \mathrm{L}$ & 0.1 \\
\hline Radium 226 and Radium 228 (combined) ( $\rho C i / L)$ & & & & & & & 5 & & 5 \\
\hline $\begin{array}{l}\text { Gross alpha particle activity } \\
\text { (excluding Ra-226. radon. and uranium ( }(\mathrm{C} i / L)\end{array}$ & & & & & & & & & 15 \\
\hline Selenium $(\mathrm{Se})(\mathrm{mg} / \mathrm{L}$ or $\mu \mathrm{g} / \mathrm{L})$ & $10 \mu \mathrm{g} / \mathrm{L}$ & $0.01 \mathrm{mg} / \mathrm{L}$ & $0.02 \mathrm{mg} / \mathrm{L}$ & $0.05 \mathrm{mg} / \mathrm{L}$ & $10 \mu \mathrm{g} / \mathrm{L}$ & & \begin{tabular}{|l|}
$0.05 \mathrm{mg} / \mathrm{L}$ \\
\end{tabular} & & 0.05 \\
\hline Silver $(\mathrm{Ag})(\mathrm{mg} / \mathrm{L})$ & & $0.05 \mathrm{mg} / \mathrm{L}$ & & & & & $0.1 \mathrm{mg} / \mathrm{L}$ & & 0.1 \\
\hline Strontium $(\mathrm{Sr})(\mathrm{mg} / \mathrm{L})$ & & & & & & & & & 4 \\
\hline Thallium $(\mathrm{TI})(\mathrm{mg} / \mathrm{L})$ & & & & & & & & & 0.002 \\
\hline Uranium $(U)(\mu g / L)$ & & & & & & & 30 & & 30 \\
\hline Vanadium $(\mathrm{V})(\mu \mathrm{g} / \mathrm{L})$ & & & & & $50 \mu \mathrm{g} / \mathrm{L}$ & & & & \\
\hline$Z i n c(Z n)(m g / L$ or $\mu g / L)$ & $200 \mu \mathrm{g} / \mathrm{L}$ & $5 \mathrm{mg} / \mathrm{L}$ & & & & & $5 \mathrm{mg} / \mathrm{L}^{5}$ & $65 \mu \mathrm{g} / \mathrm{L}$ & 2 \\
\hline Fats and oils & & & & & $15 \mathrm{mg} / \mathrm{L}$ & & & & \\
\hline Mineral oils $(m g / L \text { or } \mu g / L)^{6}$ & $5 \mu \mathrm{g} / \mathrm{L}$ & & $1.5 \mathrm{mg} / \mathrm{L}$ & $2.5 \mathrm{mg} / \mathrm{L}$ & & & & $200 \mu \mathrm{g} / \mathrm{L}$ & \\
\hline Others & & & & & & & & & \\
\hline \begin{tabular}{|l} 
Anionic detergents $(\mathrm{m} g / \mathrm{L})$ \\
\end{tabular} & & & $2 \mathrm{mg} / \mathrm{L}$ & $3 \mathrm{mg} / \mathrm{L}$ & & & & & \\
\hline
\end{tabular}



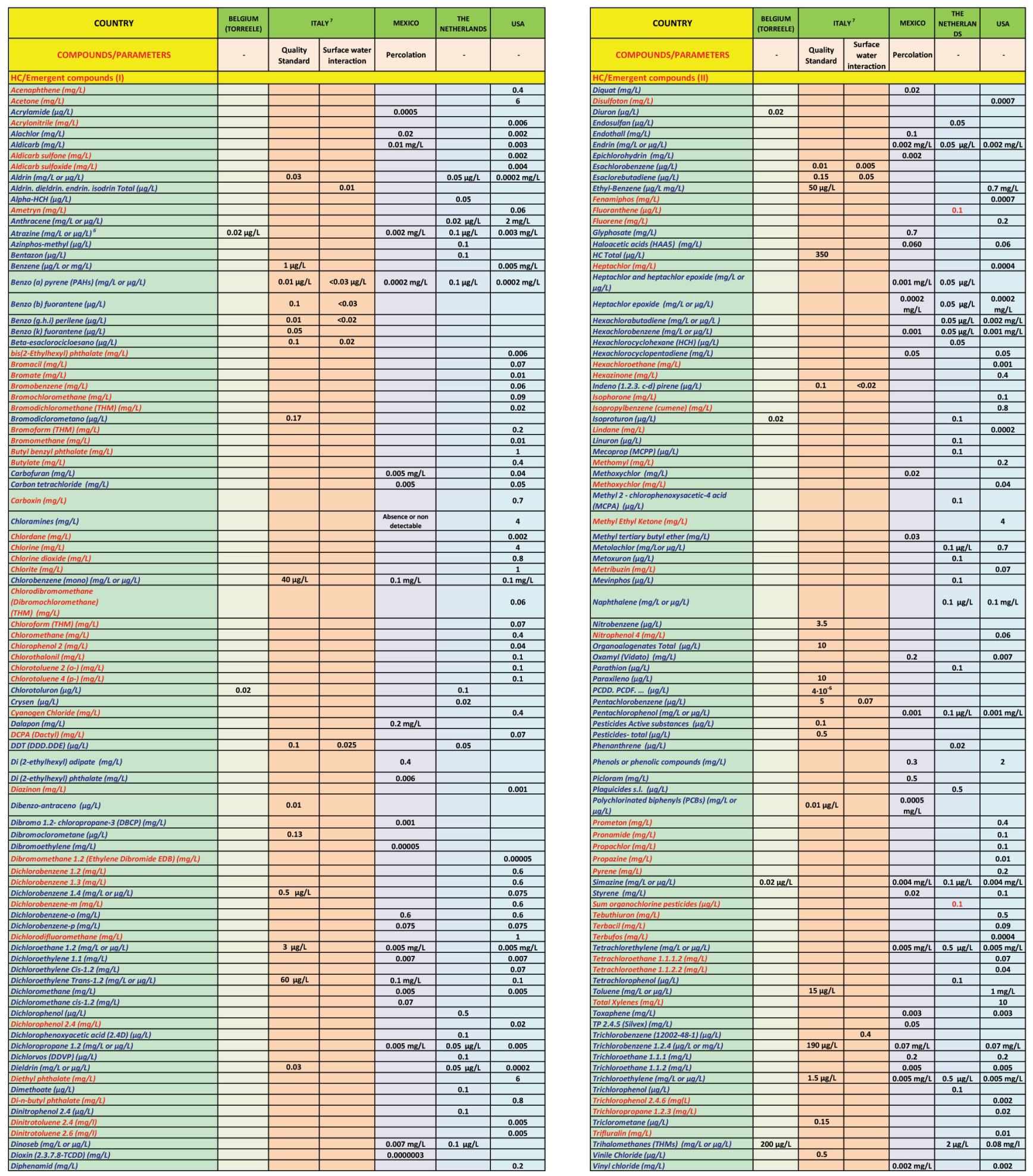

${ }^{1}$ Minimum distance between recharging infrastructure and extraction site

${ }^{2}$ Regional Water Quality Control Board No 91-121, adopted November 15.1991

${ }^{3}$ Proposed criteria for aquifer recharge with recycled water (State of California 1993)

${ }^{4}$ Minimum distance between recharging infrastructure and extraction site. Page et al. 2014 - Water Research - Determining treatment requirements for turbid river water to avoid clogging of aquifer storage and recovery wells in siliceous alluvium

${ }^{5}$ Data from Water quality data from the Fred Hervey recharge project (Bolson del Hueco Aquifer, Mexico). Extracted from State of the Art Report Healt Risks in Aquifer Recharge Using Reclaimed Water. World Health Organization 2003 Health Risks in Aquifer Recharge Using Reclaimed Water

${ }^{6}$ The units have been respected as the appear in their respective regulations

7 Values listed for the quality of the groundwater body (in case groundwater is used to recharge an aquifer, not for a surface "good chemical status" water donor body) 